\title{
Nitrogen Status Estimation of Winter Wheat by Using an IKONOS Satellite Image in the North China Plain
}

\author{
Liangliang Jia ${ }^{1,2}$, Zihui $\mathrm{Yu}^{1}$, Fei $\mathrm{Li}^{1}$, Martin Gnyp ${ }^{3}$, Wolfgang Koppe ${ }^{3}$, \\ Georg Bareth $^{3}$, Yuxin Miao ${ }^{1}$, Xinping Chen ${ }^{1, *}$, and Fusuo Zhang ${ }^{1}$ \\ ${ }^{1}$ College of Resources \& Environmental Sciences, China Agricultural University, \\ 100094, Beijing, China \\ ${ }^{2}$ Institute of Agricultural Resources \& Environment, Hebei Academy of Agriculture and \\ Forestry Sciences, 050051, Shijiazhuang, China \\ ${ }^{3}$ Department of Geography, University of Cologne, 50923, Cologne, Germany \\ jiall@cau.edu.cn
}

\begin{abstract}
The objective of this study was to determine relationship between high resolution satellite image and wheat $\mathrm{N}$ status, and develop a methodology to predict wheat $\mathrm{N}$ status in the farmers' fields. Field experiment with 5 different $\mathrm{N}$ rates was conducted in Huimin County in the North China Plain, and farmers' fields in 3 separated sites were selected as validation plots. The IKONOS image covering all research sites was obtained at shooting stage in 2006. The results showed that single band reflectance of NIR, Red and Green and vegetation indices of NDVI, GNDVI, RVI and OSAVI all well correlated with wheat N status parameters. Field validation results indicated that the prediction models using OSAVI performed well in predicting $\mathrm{N}$ uptake in the farmers' fields $\left(\mathrm{R}^{2}=\right.$ 0.735). We conclude that high resolution satellite images like IKONOS are useful tools in $\mathrm{N}$ fertilization management in the North China Plain.
\end{abstract}

Keywords: IKONOS image, vegetation indices, nitrogen status, winter wheat.

\section{Introduction}

The North China Plain is one of the most important grain yield production areas in China. Excessive $\mathrm{N}$ fertilizer application is considered as a common problem for wheat production in this area and results in low nutrient use efficiency and potentially exerts more pressure on the environment such as nitrate leaching to the ground water[1-4]. In recent years, scientists have developed several in-field soil-plant analysis methods to monitor the $\mathrm{N}$ status of various crops to optimize the timing and rate of $\mathrm{N}$ application, including the plant total $\mathrm{N}$ content and SPAD readings[5], the testing of sap nitrate in the basal stem of wheat at specific growth stage[6-7] and soil Nmin test[8-9]. All these approaches, however, need destructive sampling and laboratory analysis, which limited their applications for wheat $\mathrm{N}$ management for large areas in the North China Plain.

${ }^{*}$ Corresponding author. 
Considering these problems, some researches now focus on remote sensing methods especially using canopy multispectral reflectance or aerial photography to monitor wheat growth conditions. Aerial photography, which uses color or infrared film, has been used in detection $\mathrm{N}$ deficiency, evaluation of plant growth status and prediction of $N$ fertilizer requirements of wheat[10-11] and maize[12-14]. In these contributions, aerial photography provided high spatial resolution images of crop canopy and showed the potential of quantifying crop $\mathrm{N}$ status variation within and between fields. However, aerial photography is always restricted by the weather conditions and flying control on the ground. Another shortcoming is that aerial photography can only cover small areas with plane[12] or hellium balloon[11,15]. When it comes to regional scale, such as a county level or provincial level, the acquisition of crop canopy images will be too time-consuming and expensive.

With the development of remote sensing technology, satellites now can provide commercial, public accessible and high spatial resolution image data. For example, IKONOS or Quickbird can provide multi-spectral data of 2-4 meter resolution covering the blue to near infrared spectrum, which may be used for crop $\mathrm{N}$ management[16]. Wright et al.[17] found significant correlations between NDVI, extracted from IKONOS image, with $\mathrm{N}$ content of wheat flag leaves and pre-season $\mathrm{N}$ input. Zhang et al.[18] indicated the IKONOS image successifully estimate the rice leaves $\mathrm{N}$ content. Shou et al.[19] found significant correlations between vegetation indices (NDVI, RVI, GNDVI and DVI) and digital values of NIR, Red, Green and Blue bands extracted from a Quickbird image with $\mathrm{N}$ status indicators (chlorophyll meter readings, stem sap nitrate concentration, aboveground biomass and shoot $\mathrm{N}$ concentration at shooting stage). However, all these researches were conducted in small and controlled experiments. Studies conducted in real farmers' fields, especially in overfertilized fields in the North China Plain, and which transfer the small experimental based studies results to farmers fields $\mathrm{N}$ recommendation, are very limited. Therefore, the objective of this research was to use high spatial resolution, multispectral satellite image to predict winter wheat $\mathrm{N}$ status in farmers' fields at the shooting stage, which was the critical $\mathrm{N}$ sensitive stage to wheat, and evaluate this approach against conventional soil and plant sampling methods.

\section{Material and Methods}

\subsection{The Experiments}

\subsubsection{Experiment 1: Nitrogen Fertilization Rate Experiment}

A winter wheat field experiment was conducted in 2005/2006 in Zijiao town, Huimin County in Shandong province in the North China Plain. This area was representative for soil and crop management in North China Plain. The soil of the experimental field was fine-loam with total nitrogen of $0.79 \mathrm{~g} / \mathrm{kg}$, Olsen $\mathrm{P}$ of $14.2 \mathrm{mg} / \mathrm{kg}$, exchangeable 
$\mathrm{K}$ of $201.5 \mathrm{mg} / \mathrm{kg}$ and organic matter content of $13.8 \mathrm{~g} / \mathrm{kg}$ in the $0-30 \mathrm{~cm}$ layer. The experiment included 5 pre-plant $\mathrm{N}$ levels of $0,25,50,75$ and $100 \mathrm{~kg} / \mathrm{ha}$ with 4 replications. The pre-plant $\mathrm{N}$ levels covered the basal fertilization rate on the North China Plain. At shooting stage, each plot was divided into two parts, one received no $\mathrm{N}$ topdressing while for the other part $\mathrm{N}$ topdressing was applied. The fertilization rate was determined based on an improved Nmin method[8]. The detailed $\mathrm{N}$ fertilization management practices in this research are described in Table 1. The area of each plot was $150 \mathrm{~m}^{2}(10 \mathrm{~m} \times 15 \mathrm{~m})$. All plots received $120 \mathrm{~kg} / \mathrm{ha} \mathrm{P}_{2} \mathrm{O}_{5}$ as triple super-phosphate and $90 \mathrm{~kg} / \mathrm{ha} \mathrm{K}_{2} \mathrm{O}$ as potassium sulfate before wheat sowing in order to avoid soil $\mathrm{P}$ and $\mathrm{K}$ deficiency. The wheat variety Lumai 23 was sown on 14 October, 2005, and harvested on 10 June, 2006.

Table 1. N fertilizer management of the winter wheat experiment

\begin{tabular}{lccccc}
\hline N fertilizer management & 1 & 2 & 3 & 4 & 5 \\
\hline Nmin before sowing (0-60 cm, kg/ha) & 49 & 59 & 81 & 98 & 95 \\
Basal N fertilizer (kg/ha) & 0 & 25 & 50 & 75 & 100 \\
N topdressing rate (kg/ha) & 113 & 107 & 94 & 55 & 54 \\
Total N input (kg/ha) & 49 & 84 & 131 & 173 & 195 \\
\hline
\end{tabular}

\subsubsection{Experiment 2: Farmers' Fields}

Besides the field experiment, three separate sites of Xujia, Xili and Shizhang were selected as the sub-study areas (Figure 1), which included 10, 12 and 16 farmers' fields, respectively. The sites were selected due to similar wheat varieties were planted in each sites. All the farmers' fields were managed by the farmers themselves, and the basal and topdressing nitrogen fertilization rates for the selected fields were summarized in Table 2 .

Table 2. The average basal N fertilization rate for the selected farmers' fields in 2005/2006 wheat season

\begin{tabular}{lccccc}
\hline Sites & $\begin{array}{c}\text { Total area } \\
(\text { ha })\end{array}$ & $\begin{array}{c}\text { Number } \\
\text { of Fields }\end{array}$ & Varieties & Planting date & $\begin{array}{c}\text { Averaged basal } \\
\text { N rate (kg/ha) }\end{array}$ \\
\hline Xujia & 3.81 & 12 & JM21 & 14, Oct. 2005 & $117(58-180)$ \\
Xili & 4.00 & 16 & JM23 & 15, Oct, 2005 & $149(49-316)$ \\
Shizhang & 3.75 & 10 & JM22 and LM23 & 18, Oct, 2005 & $78(34-120)$ \\
\hline
\end{tabular}




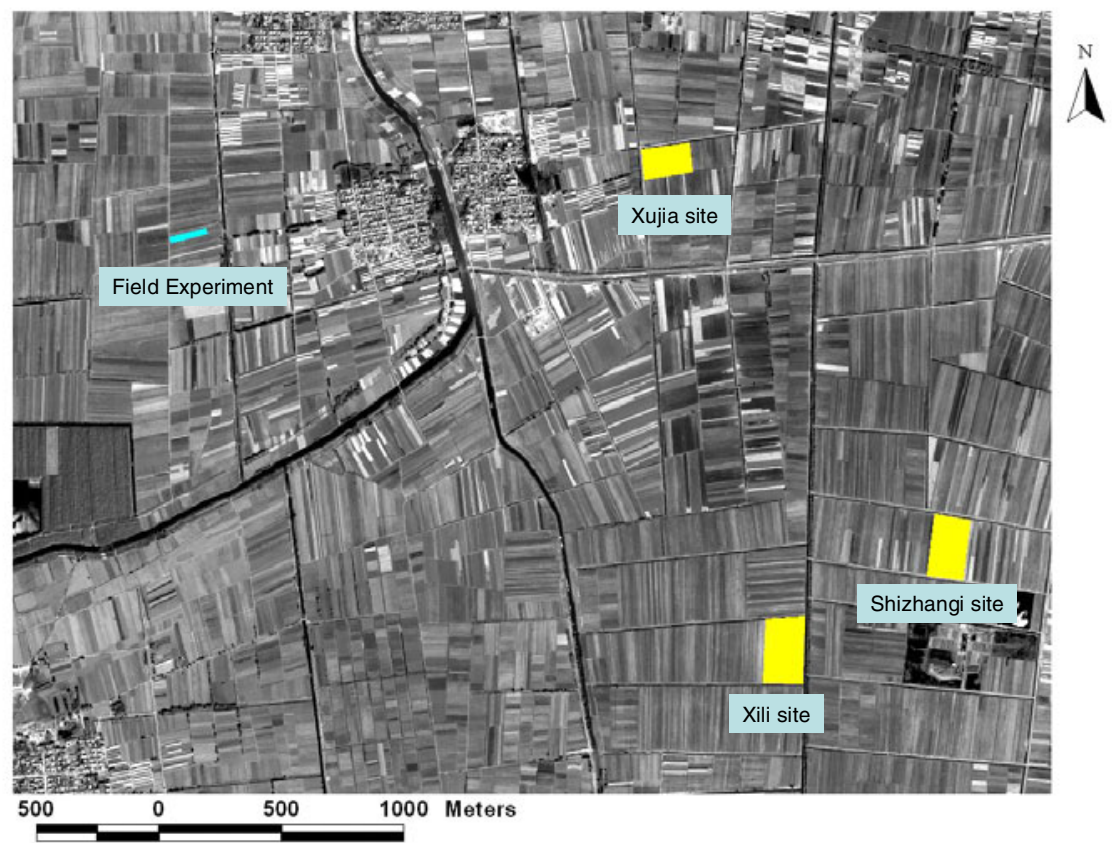

Fig. 1. The distribution of experiment and research sites at 2005/2006 wheat season in Huimin County, Shandong Province

\subsection{Field Survey and Agronomic Measurements}

Wheat $\mathrm{N}$ status indicators were measured at the shooting stage in Apr. 10, 2006. The nitrate concentration of the plant stem sap was determined with a Reflect Meter (Merck Co., Darmstadt, Germany), and SPAD readings were taken on the uppermost fully expanded leaves from 30 randomly selected plants in per plot and the average value was used for further analysis. Five soil cores were collected from each plot and pooled at 0 to $30 \mathrm{~cm}, 30$ to $60 \mathrm{~cm}$, and 60 to $90 \mathrm{~cm}$ depth intervals. To analyze the soil Nmin, all samples were sieved, extracted with $0.01 \mathrm{M} \mathrm{CaCl} 2$ and analyzed for NH4+-N and NO3--N by continues flow analyzer TRAACS 2000[20]. The soil Nmin was used to determine the optimum $\mathrm{N}$ topdressing rate at shooting stage as described by Chen et al.[8]. Aboveground wheat biomass were harvested $\left(1 \mathrm{~m}^{2}\right.$ per plot) for the experiment, and dried at $60{ }^{\circ} \mathrm{C}$ to constant weight for biomass dry weight, and then analyzed for total $\mathrm{N}$ concentration using Kjeldahl digestion method.

For the selected farmers' fields in Xili, Xujia and Shizhang sites, only the aboveground plant biomass and total shoot $\mathrm{N}$ concentration were determined at shooting stage. 
A "Trimble-AgGPS ${ }^{\circledR}$ 132" GPS receiver was used to georeference the sampling points in the experiment and farmers' fields, and the boundaries of the experiment plots.

\subsection{IKONOS Image Processing}

The IKONOS images, which included 4-m resolution multispectral bands (Blue band: 0.45-0.53 $\mu \mathrm{m}$; Green band: 0.52-0.61 $\mu \mathrm{m}$; Red: band 0.64-0.72 $\mu \mathrm{m}$; and NIR band: $0.77-0.88 \mu \mathrm{m})$ and $1 \mathrm{~m}$ resolution panchromatic band $(0.45-0.90 \mu \mathrm{m})$, were acquired on Apr. 20th, 2006, at the shooting stage of winter wheat. Since no temporal comparison or with other imagery was planned, the atmospheric corrections in this research was not performed [21]. The collected DGPS points at the transaction points around the study sites were converted to shapefiles using ArcGIS 8.1 and were imported into ENVI 4.2 as a vector layer. This layer was used to georectify the IKONOS image and to extract the plotted pixels' raw digital spectral reflectance values of NIR, Red, Green and Blue bands. At least 3 pixels in each experiment plots were used to get averaged raw digital spectral reflectance values.

\subsection{Data Analysis}

The vegetation indices (VIs) of NDVI (normalized vegetation index[22]), RVI (ratio vegetation index[23]), GNDVI (green vegetation index[24]) and OSAVI (optimized soil-adjusted vegetation index[25]) were calculated for the obtained IKONOS satellite image. The detailed expressions of the vegetation indices were listed in Table 3.

Table 3. Broadband vegetation indices used for image analysis

\begin{tabular}{|c|c|c|c|}
\hline Abbreviation & Name & Vegetation Index & Reference \\
\hline NDVI & $\begin{array}{l}\text { Normalized } \\
\text { Difference } \\
\text { Vegetation Index }\end{array}$ & NDVI $=($ NIR-Red $) /(\mathrm{NIR}+\mathrm{Red})$ & $\begin{array}{l}\text { Rouse et al., } \\
1973\end{array}$ \\
\hline RVI & $\begin{array}{l}\text { Ratio Vegetation } \\
\text { Index }\end{array}$ & $\mathrm{RVI}=\mathrm{NIR} / \mathrm{Red}$ & Jordan, 1969 \\
\hline GNDVI & $\begin{array}{l}\text { Green Normalized } \\
\text { Difference } \\
\text { Vegetation Index }\end{array}$ & GNDVI=(NIR-Green)/(NIR+Green $)$ & $\begin{array}{l}\text { Gitelson and } \\
\text { Merzlyak, } \\
1998\end{array}$ \\
\hline OSAVI & $\begin{array}{l}\text { Optimized soil- } \\
\text { adjusted } \\
\text { vegetation index }\end{array}$ & OSAVI $=(\mathrm{NIR}-\mathrm{Red}) /(\mathrm{NIR}+\mathrm{Red}+0.16)$ & $\begin{array}{l}\text { Rondeaux et } \\
\text { al., } 1996\end{array}$ \\
\hline
\end{tabular}

Nitrogen effects were analyzed quantitatively by comparing the means of agronomic parameters of each treatment through LSD test at a probability of 0.05 . 
The single band reflectance of R, G, B and NIR bands and the vegetation indices of NDVI, GNDVI, RVI and OSAVI were regressed with the chlorophyll meter readings (SPAD), soil $\mathrm{N}$ input before sowing (including initial $\mathrm{Nmin}$ and basal $\mathrm{N}$ ), stem sap nitrate concentration, shoot $\mathrm{N}$ concentration, aboveground biomass and nitrogen uptake. The regressions of single bands reflectance and VIs with plant $\mathrm{N}$ status indicators were made using Statistical Analysis System version 8.1 [26]. Linear or nonlinear models were fitted based on the plot patterns and best-fit $\mathrm{R}^{2}$ values for the relationship. When linear relationships were not significant, exponential or logarithm models were attempted. Then the best-fit models were used to predict, nitrogen uptake in the farmers' fields. The root mean square error (RMSE) and relative error was calculated to compare the precision of estimation between the measured values $(\mathrm{X})$ and the estimated values (X').

\section{$3 \quad$ Results}

\subsection{Nitrogen Status of Wheat at Shooting Stage}

The $\mathrm{N}$ status of winter wheat at shooting stage was significantly affected by the $\mathrm{N}$ treatments (Table 4). High $\mathrm{N}$ supply (initial soil Nmin + pre-plant $\mathrm{N}$ fertilization) led to high SPAD readings, aboveground biomass, shoot $\mathrm{N}$ concentration, stem sap nitrate concentration and total $\mathrm{N}$ uptake. The significant difference among the 5 pre- $\mathrm{N}$ treatments showed that the low $\mathrm{N}$ supply treatments of 1 and 2 were in the state of $\mathrm{N}$ deficiency, having lower aboveground biomass, SPAD readings, stem sap nitrate concentration and $\mathrm{N}$ uptake than the high $\mathrm{N}$ treatments of 4 and 5, which were in the state of over fertilization. The treatment 3 seemed to have optimum $\mathrm{N}$ status with relatively high SPAD readings and stem sap nitrate concentration.

Table 4. Nitrogen status of winter wheat at shooting stage

\begin{tabular}{lccccc}
\hline Items $\backslash$ Treatments & 1 & 2 & 3 & 4 & 5 \\
\hline Nmin $(0-90 \mathrm{~cm})$ & $56 \mathrm{~b}$ & $62 \mathrm{~b}$ & $82 \mathrm{~b}$ & $124 \mathrm{a}$ & $112 \mathrm{a}$ \\
Chlorophyll meter readings (SPAD) & $46.2 \mathrm{c}$ & $48.2 \mathrm{~b}$ & $49.6 \mathrm{a}$ & $50.1 \mathrm{a}$ & $50.6 \mathrm{a}$ \\
Upland biomass (kg/ha) & $852 \mathrm{c}$ & $1137 \mathrm{c}$ & $1273 \mathrm{~b}$ & $1543 \mathrm{ab}$ & $1703 \mathrm{a}$ \\
Shoot N concentration $(\mathrm{g} / \mathrm{kg})$ & $32.4 \mathrm{c}$ & $32.7 \mathrm{bc}$ & $33.8 \mathrm{bc}$ & $36.6 \mathrm{ab}$ & $37.8 \mathrm{a}$ \\
N uptake $(\mathrm{kg} / \mathrm{ha})$ & $27.5 \mathrm{~d}$ & $36.9 \mathrm{~cd}$ & $43.5 \mathrm{bc}$ & $57.0 \mathrm{ab}$ & $63.6 \mathrm{a}$ \\
Stem nitrate Concentration $(\mathrm{mg} / \mathrm{kg})$ & $1228 \mathrm{c}$ & $1295 \mathrm{c}$ & $1672 \mathrm{~b}$ & $1834 \mathrm{ab}$ & $1955 \mathrm{a}$ \\
\hline
\end{tabular}

*Means with different letter are significant different at 0.05 level.

\subsection{Correlations of Vegetation Indices with Wheat N Status at Shooting Stage}

Significant correlations were found between NDVI, RVI and GNDVI with SPAD readings, stem sap nitrate concentration, aboveground biomass and nitrogen uptake at shooting stage $\left(\mathrm{R}^{2}=0.488-0.739\right)$ (Table 5). All of the single band reflectance of 
NIR, Red and Green had significant correlations with SPAD, stem sap nitrate concentration, biomass and $\mathrm{N}$ uptake $\left(\mathrm{R}^{2}=0.240-0.645\right)$, which were lower than those with VIs. Neither VIs nor single band reflectance used in this research could significantly explain wheat $\mathrm{N}$ concentration variation $\left(\mathrm{R}^{2}=0.008-0.397\right)$, but the high $\mathrm{R}^{2}$ values with aboveground biomass $\left(\mathrm{R}^{2}=0.667-0.708\right)$ and nitrogen uptake $\left(\mathrm{R}^{2}\right.$ $=0.678-0.739)$ suggested that VIs could still be used to explain $\mathrm{N}$ and growth status of wheat at shooting stage.

Table 5. Coefficient of determination $\left(\mathrm{R}^{2}\right)$ for wheat $\mathrm{N}$ status with single band digital value and vegetation indices derived from IKONOS satellite image at shooting stage

\begin{tabular}{lccccc}
\hline R2 & SPAD & Stem sap nitrate & Biomass & N Content & N uptake \\
\hline NIR & $0.424^{*}$ & $0.434^{*}$ & $0.572^{*}$ & 0.291 & $0.615^{* *}$ \\
Red & $0.645^{* *}$ & $0.342^{*}$ & $0.501^{*}$ & 0.046 & $0.430^{*}$ \\
Green & $0.483^{*}$ & $0.352^{*}$ & $0.426^{*}$ & 0.008 & $0.329 *$ \\
Blue & 0.284 & 0.318 & 0.297 & 0.015 & 0.240 \\
NDVI & $0.707 * *$ & $0.507^{*}$ & $0.704 * *$ & 0.181 & $0.678^{* *}$ \\
GNDVI & $0.647 * *$ & $0.541^{*}$ & $0.708^{* *}$ & 0.184 & $0.683^{* *}$ \\
RVI & $0.686^{* *}$ & $0.537^{*}$ & $0.667 * *$ & 0.199 & $0.704^{* *}$ \\
OSAVI & $0.678^{* *}$ & $0.513^{*}$ & $0.707 * *$ & $0.397 *$ & $0.739 * *$ \\
\hline
\end{tabular}

$* L S D=0.05, * * L S D=0.01$, number of observations $=20$.

\subsection{Nitrogen Uptake Estimation of Winter Wheat for Farmers' Fields}

The $\mathrm{N}$ uptake of the winter wheat at shooting stage for farmers' fields in Xili, Shizhang, Xujia and Xizhangliu were predicted using the relationships developed with the experimental data (Figure 2). The estimated $\mathrm{N}$ uptake values using any of the four vegetation indices were all significantly correlated with measured values. Considering the normally farmers $\mathrm{N}$ application rate of $277-441 \mathrm{~kg} / \mathrm{ha}$ in this region, the RMSE for NDVI and OSAVI were acceptable (26.6-27.4 kg/ha) while the RMSE for RVI and GNDVI were too high $(42.2-61.0 \mathrm{~kg} / \mathrm{ha})$ to be acceptable by the farmers. Compared with the other vegetation indices used in this research, OSAVI was the best for nitrogen uptake prediction (closest to 1:1 line), while $\mathrm{N}$ uptake predicted with RVI and GNDVI were either higher or lower than measured values at the state of high $\mathrm{N}$ uptake. The results suggested that NDVI and OSAVI derived from IKONOS satellite image could be used for monitoring and estimating of wheat growth and nitrogen status. 

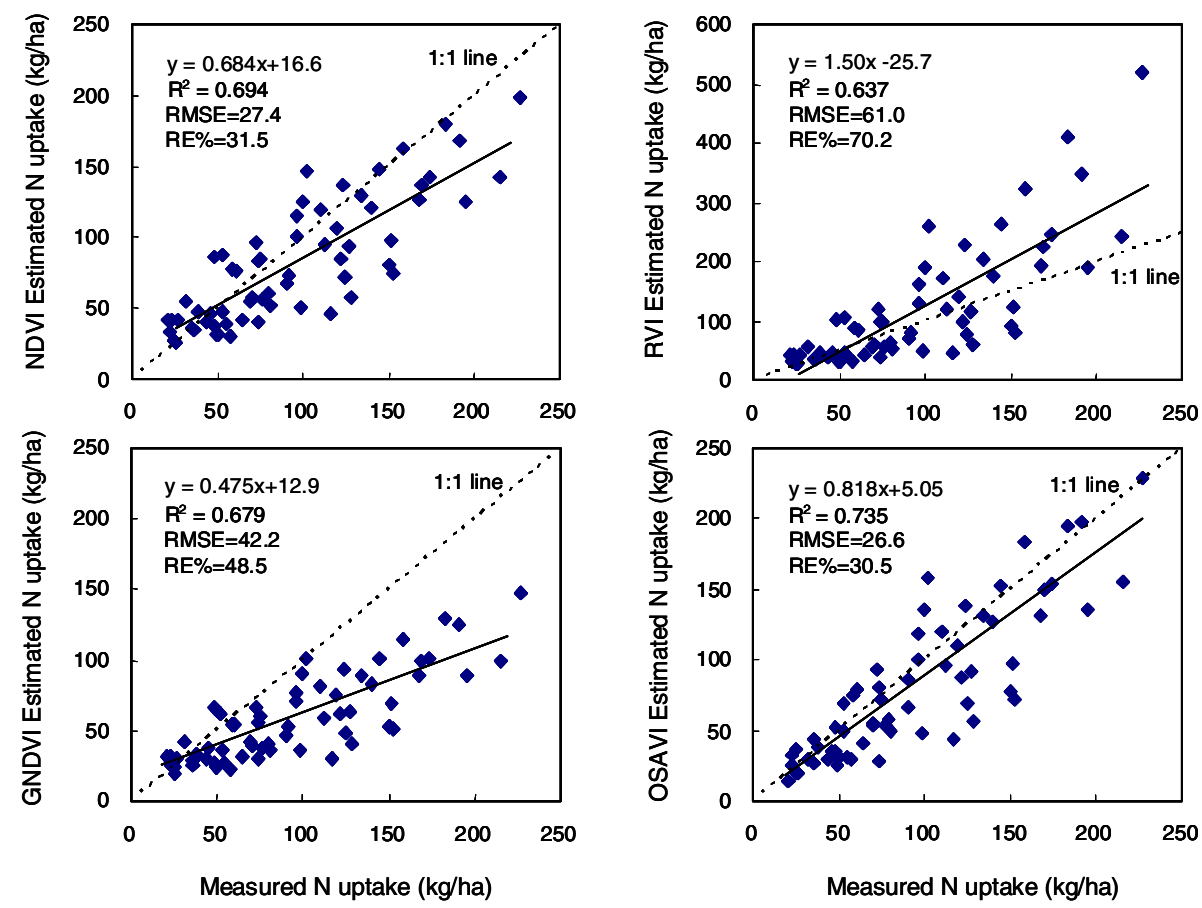

Fig. 2. Comparison of the accuracy of the measured $\mathrm{N}$ uptake at shooting stage with predicted $\mathrm{N}$ uptake in the farmer's field (RMSE = root mean square error; RE\% = relative error; number of observations $=84$ )

\section{Discussion}

A very important approach to precision $\mathrm{N}$ management is to detect crop $\mathrm{N}$ status during the growing season and use this information to guide in-season $\mathrm{N}$ management. Traditional soil-plant analysis methods, such as SPAD, biomass, shoot $\mathrm{N}$ concent and soil Nmin, are either destructive or too time- and money-intensive for regional investigation. High resolution multispectral satellite imagary provides a promising solution for non-destructive and fast estimation of crops growth and $\mathrm{N}$ status. The vegetation indices used in this research all showed significant correlations with wheat $\mathrm{N}$ status indicators of SPAD readings, stem sap nitrate concentration, upland biomass and nitrogen uptake, but not with shoot $\mathrm{N}$ concentration. These results differ from earlier findings by Shou et al.[19] and Wright et al.[17], which showed that vegetation indices derived from Quickbird satellite image had significant correlations with shoot $\mathrm{N}$ concentration. An explanation of the low correlations of IKONOS image with shoot $\mathrm{N}$ concentration is that rapid wheat aboveground biomass increase at shooting stage causes unstable changes of the shoot $\mathrm{N}$ concentration when field measurements and satellite image were taken. Measurements at later growing 
stages and corresponding image acquisition may have a better relationship. More studies are needed to test this hypothesis.

The successful estimation of the nitrogen uptake in overfertilized farmers' fields, rather than in control experiments[27-30], supported the idea suggested by Shou et al.[19] to use high resolution satellite image combined with in-site soil-plant analysis at small reference fields to monitor regional nitrogen status of winter wheat in North China Plain.

The fast development of the satellite technologies have made the acquisition of high spatial and spectral resolution satellite images become cheaper and easier than before. In recent years, some researchers have considered hyperspectral sensors to monitor rice nitrogen status and nutrients disorder[31] and satellites with radar systems (SAR) to study soil and crop moisture[32-33] and forest biomass [34](Austin et al., 2003). Although more sensors have been used in monitoring vegetation growth status than before, satellite images for agriculture uses still face many challenges, such as clouds or dust which interfere the acquisition or quality of the image, low spectral resolution in explaining the canopy and canopy reflectance disorders caused by other factors except nutrients, etc. A possible solution to this problem is multisource remote sensing data fusion. For example, high spatial resolution IKONOS or Quickbird satellite images combined with high spectral resolution EO-1 Hyperion and soil-plant analysis may provide better explanations for crop canopy nutrient disorders. In such studies, plots with optimum $\mathrm{N}$ management should be included to provide reference values. This may allow the development of site-specific fertilizer recommendation maps as described by Scharf and Lory[12]. Further researches are needed to verify this idea and develop a robust system that will allow farmers to access these data to improve their management decisions.

Acknowledgements. This research was financially supported by the Special Fund for Agro-scientific Research in the Public Interest (201103003), the Program for Changjiang Scholars and Innovative Research Team in University of China (IRT 0511), International Bureau of the BMBF, Germany and the GIS \& RS Group of the University of Cologne.

\section{References}

1. Zhao, R.F., Chen, X.P., Zhang, F.S., Zhang, H.L., Schroder, J., Roemheld, V.: Fertilization and nitrogen balance in a Wheat-Maize Rotation System in North China. Agronomy Journal 98, 938-945 (2006)

2. Ju, X.T., Kou, C.L., Christile, P., Dou, Z.X., Zhang, F.S.: Changes in the soil environment from excessive application of fertilizers and manures to two contrasting intensive cropping systems on the North China Plain. Environmental Pollution 145, 497-506 (2007)

3. Gao, W., Huang, J., Wu, D., Li, X.: Investigation on nitrate pollution in ground water at intensive agricultural region in Huanghe-huaihe-haihe Plain. Ecological Agriculture Research 7, 41-43 (1999); (in Chinese with English abstract)

4. Zhang, W.L., Tian, Z.X., Zhang, N., Li, X.Q.: Nitrate pollution of groundwater in northern China. Agriculture Ecosystem and Environment 59, 223-231 (1996) 
5. Blackmer, T.M., Schepers, J.S.: Analysis of aerial photography for nitrogen. Agronomy Journal 88, 729-733 (1996)

6. Fox, R.H., Roth, G.W., Lversen, K.V., Piekielek, W.P.: Soil and tissue nitrate tests compared for predicting soil nitrogen availability to corn. Agronomy Journal 81, 971-974 (1989)

7. Li, Z.H., Zhang, F.S., Wang, X.R.: Nitrogen nutritional diagnosis and recommendation as topdressing fertilizer $\mathrm{N}$ for several crops in North China: diagnosis of nitrate in plant tissue by quick test method. Plant Nutrition and Fertilizer Science 3, 269-274 (1997); (in Chinese with English abstract)

8. Chen, X.P., Zhang, F.S., Roemheld, V., Horlacher, D., Schulz, R., Boening-Zilkens, M., Wang, P., Claupein, W.: Synchronizing N supply from soil and fertilizer and N demand of winter wheat by an improved Nmin method. Nutrient Cycling in Agroecosystems 74, 91-98 (2006)

9. Cui Z.L.: Optimization of the $\mathrm{N}$ fertilizer management for a winter wheat - summer maize rotation system in the Northern China Plain - from field to regional scale. Ph.D. Dissertation, China Agricultural University, Beijing, China (in Chinese with English abstract) (2005)

10. Flowers, M., Weisz, R., Heiniger, R.: Remote sensing of winter wheat tiller density for early nitrogen application decisions. Agronomy Journal 93, 783-789 (2001)

11. Jia, L.L., Chen, X.P., Zhang, F.S., Buerkert, A., Roemheld, V.: Low altitude aerial photography for optimum $\mathrm{N}$ fertilization of winter wheat on the North China Plain. Field Crops Research 89, 389-395 (2004)

12. Scharf, P.C., Lory, J.A.: Calibrating corn color from aerial photographs to predict sidedress nitrogen need. Agronmy Journal 94, 397-404 (2002)

13. Sripada, R.P., Heiniger, R.W., White, J.G., Weisz, R.: Aerial Color Infrared Photography for Determining Late-Season Nitrogen Requirements in Corn. Agronomy Journal 97, 1443-1451 (2005)

14. Sripada, R.P., Heiniger, R.W., White, J.G., Meijer, A.D.: Aerial Color Infrared Photography for Determining Early In-Season Nitrogen Requirements in Corn. Agronomy Journal 98, 968-977 (2006)

15. Gerard, B., Buerkert, A.: Estimation of spatial variablity in pearl millet growth with nondestructive methods. Expl. Agric. 37, 373-389 (2001)

16. Franizer, P., Lamb, D., Kumar, L.: Remote sensing and satellite image technology: capabilities and implementation (2005),

http: / /www.frfa.asn.au/files/pdf/conference/papers

17. Wright, D.L., Rasmussen, V.P., Ramsey, R.D., Baker, D.J.: Canopy reflectance estimation of wheat nitrogen content for grain protein management. GIScience and Remote Sensing 41, 287-300 (2004)

18. Zhang, J.H., Wang, K., Bailey, J.S., Wang, R.C.: Predicting nitrogen status of rice using multispectral data at canopy scale. Pedosphere 16(1), 108-117 (2006)

19. Shou, L.N., Jia, L.L., Cui, Z.L., Chen, X.P., Zhang, F.S.: Using high-resolution satellite image to evaluate nitrogen status of winter wheat in the North China Plain. Journal of Plant Nutrition 30(10), 1669-1680 (2007)

20. Bran and Luebbe: Bran+Luebbe Traacs 2000 continuous flow analyzer operation manual. MT9, GB-352-87A and GB-352-87E. Publication No. MT7-50EN-01. Bran+Luebbe GmbH, Norderstedt, Germany (1996)

21. Song, C., Woodcock, C.E., Seto, K.C., Pax-Lenny, M., Macomber, S.A.: Classification and change detection using Landsat TM Data: When and How to Correct Atmospheric Effects? Remote Sensing of Environment 75, 230-244 (2001) 
22. Rouse, J.W., Has, R.H., Schell, J.A., Deering, D.W.: Monitoring vegetation systems in the great plains with ERTS. In: Third ERTS Symposium, NASA SP-351, vol. 1, pp. 309-317. NASA, Washington, DC (1973)

23. Jordan, F.: Derivation of leaf area index from quality of light on the forest floor. Ecology 50, 663-666 (1969)

24. Gitelson, A., Merzlyak, N.: Remote sensing of chlorophyll concentration in higher plant leaves. Advances in Space Research 22, 689-692 (1998)

25. Rondeaux, G., Steven, M., Baret, F.: Optimization of soil-adjusted vegetation indices. Remote Sensing and Environment 58, 1-12 (1996)

26. SAS Institute.: SAS/STAT user's guide. Version 8.1. SAS Inst., Cary, NC (1998)

27. Xue, L.H., Cao, W.X., Luo, W.H., Dai, T.B., Zhu, Y.: Monitoring leaf nitrogen status in rice with canopy spectral reflectance. Agronomy Journal 96, 135-142 (2004)

28. Chang, K., Shen, W.Y., Lo, J.-C.: Predicting rice yield using canopy reflectance measured at booting stage. Agronomy Journal 97, 872-878 (2005)

29. Elwadie, M.E., Pierce, F.J., Qi, J.: Remote sensing canopy dynamics and biophysical variables estimation of corn in Michigan. Agronomy Journal 97, 99-105 (2005)

30. Ferrio, J., Villegas, P.D., Zarco, J., Aparicio, N., Araus, J.L., Roco, C.: Assessment durum wheat yield using visible and near-infrared reflectance spectra of canopies. Field Crops Research 94, 126-148 (2005)

31. Chen, J.Y., Tian, Q.J.: Estimating canopy chlorophyll and nitrogen concentration of rice from EO-1 Hyperion data. In: Manfred, O., D’Urso, G., Neale, C.M.U., Gouweleeuw, B.T. (eds.) Proceedings of SPIE Remote Sensing for Agriculture, Ecosystems, and Hydrology VIII, October 3, vol. 6359, p. 63591H (2006)

32. Leconte, R., Brissette, F., Galarneau, M., Rousselle, J.: Mapping near-surface soil moisture with RADARSAT-1 synthetic aperture radar data. Water Resources Research 40, 1029-1038 (2004)

33. Griffiths, G., Wooding, M.: Temporal Monitoring of Soil Moisture Using ERS-1 SAR Data. Hydrological Processes 10, 1127-1138 (1996)

34. Austin, J.M., Mackey, B.G., Van Niel, K.P.: Estimating forest biomass using satellite radar: an exploratory study in a temperate Australian Eucalyptus forest. Forest Ecology and Management 176, 575-583 (2003) 